\title{
Management of acromegaly
}

\section{Vladimir Vasilev ${ }^{1,2}$, Adrian Daly ${ }^{1}$, Sabina Zacharieva ${ }^{2}$ and Albert Beckers ${ }^{1 *}$}

\author{
Addresses: ${ }^{1}$ Department of Endocrinology, Centre Hospitalier Universitaire de Liège, University of Liège, 4000 Liège, Belgium; ${ }^{2}$ Clinical Centre of \\ Endocrinology and Gerontology, Medical University, 2 Zdrave St, 1431 Sofia, Bulgaria \\ *Corresponding author: Albert Beckers (albert.beckers@chu.ulg.ac.be) \\ FI000 Medicine Reports 2010, 2:54 (doi:I0.3410/M2-54)
}

The electronic version of this article is the complete one and can be found at: http://fl000.com/reports/medicine/content/2/54

\begin{abstract}
Acromegaly is caused by hypersecretion of growth hormone and resultant overproduction of insulinlike growth factor-I and is associated with increased mortality and morbidity. Successful treatment modalities have been developed and are used in a multistep approach allowing normal life expectancy as well as improved quality of life in an increasing number of patients.
\end{abstract}

\section{Introduction and context}

Acromegaly is a chronic progressive disorder due to growth hormone (GH) hypersecretion and subsequent elevated levels of insulin-like growth factor-1 (IGF-1). In over $95 \%$ of cases the etiology can be attributed to GHproducing benign pituitary adenoma [1]. With an estimated prevalence of 40-70 cases per million and an incidence of 3-5 new cases per million [2], it ranks as a rare disease. Several recent studies suggest, however, that these rates may be underestimates and report prevalence rates up to 130 cases per million $[3,4]$ or even 1000 cases per million for biochemical acromegaly, defined by elevated IGF-1 levels [5]. Excess GH secretion leads to disproportionate skeletal growth, coarse facial features, soft tissue swelling as well as metabolic disorders and a tendency for malignancies that inexorably result in increased mortality and morbidity rates if the disease is left untreated. Since these unfavorable effects have insidious onset, the diagnosis is often delayed up to 7 years after initial presentation of symptoms $[1,6]$. Although significant advances have been made in the past decades with the introduction of highly sensitive assays for GH and IGF-1, relatively little progress has been achieved in early recognition.

Mortality rates are closely related to the degree of GH and IGF-1 hypersecretion and reducing their levels to normal ranges can confer life expectancy similar to that of the general population [7]. Therapeutic goals include control of GH and IGF-1 levels, tumor volume reduction for alleviating symptoms of mass effect and concomitant neurological disorders, preservation of pituitary function, improvement of long-term mortality and morbidity, and prevention of disease recurrence as well as increasing the quality of life of patients.

\section{Recent advances}

Several consensus statements and clinical guidelines [8-11] have been published recently clearly defining criteria for good disease control: suppression of GH to $<0.4 \mu \mathrm{g} / \mathrm{l}$ during oral glucose tolerance test or random $\mathrm{GH}$ values $<1 \mu \mathrm{g} / \mathrm{l}$ (using ultrasensitive assays) and ageadjusted normal levels of IGF-1. Strategies are now available to help physicians achieve more effective treatment of acromegaly. Surgery, pharmacological therapy, and radiotherapy are employed in a step-like approach to maintain disease control.

\section{Surgery}

Transsphenoidal surgery is the preferred first-line treatment for patients with acromegaly that have intrasellar microadenomas, noninvasive macroadenomas or patients in whom the tumor is causing compression symptoms. Surgery can lead to rapid normalization of GH levels, it relieves symptoms of compression if present and may achieve total cure in up to $56-70 \%$ of appropriate patients $[12,13]$. Major predictors of outcome of surgery are tumor size and invasiveness, 
preoperative GH levels, and experience of the neurosurgical team. In patients with well-circumscribed microadenoma, success rates may reach $78-95 \%$, while invasive macroadenomas, constituting more than two-thirds of cases at diagnosis, can be controlled in less than 50\% $[12,14]$. Nevertheless, surgical debulking of unresectable adenomas may result in better postoperative control with somatostatin receptor ligands (SRLs) $[15,16]$. The scope of lesions that can be successfully removed is further widened by recently developed technical advances, such as endoscope-assisted microsurgery, three-dimensional navigation, and intra-operative magnetic resonance imaging, but properly conducted comparative studies are still lacking.

\section{Pharmacological therapy}

Three classes of drugs are currently available for the treatment of acromegaly: SRLs, GH receptor antagonists, and dopamine agonists. Pharmacological therapy is mainly indicated when surgery fails to achieve remission but is increasingly considered as primary medical treatment. The traditional subgroups of patients that were considered as good candidates for primary medical therapy (mainly with SRLs) included patients with contraindications to, or unwillingness to undergo, operative intervention or those with tumors unlikely to be cured by surgery alone [8]. A recent study has suggested that SRLs might have similar utility to surgery as first-line primary therapy in unselected patients, although confirmatory data are awaited [17].

\section{Somatostatin receptor ligands}

SRLs are analogues of natural somatostatin and exert their effects by binding to somatostatin receptors (SSTRs) on pituitary somatotrope cells, thus suppressing GH secretion. Commercially available drugs include octreotide and lanreotide and long-acting preparations have been developed for both molecules, increasing patient comfort and compliance. These agents effectively lower GH levels to $<1 \mu \mathrm{g} / \mathrm{l}$ in 48 $57 \%$ and normalize IGF-1 levels in $47-67 \%$ of patients as shown in a recent meta-analysis [18]. However, many patients in clinical trials were pre-selected for responsiveness to SRL and lesser efficacy may be expected in unselected populations. When applied as primary therapy in unselected patients, they achieved normalization of GH and IGF-1 in 34\% and $44 \%$ of subjects, respectively [19]. Apart from their antisecretory efficacy, SRLs also reduce tumor volume in approximately $24-57 \%$ of patients, with greater effect when used as primary therapy (30-80\%) compared to adjuvant treatment $(9-28 \%)$ [20]. Their role as primary medical therapy is still evolving. Current guidelines advocate SRLs in selected patients whose co-morbidities present a risk for surgery and also in patients who have invasive tumors where complete removal is unlikely [8]. Controversy also exists over whether SRLs should be considered as pre-operative treatment. In a recent study Carlsen et al. [21] showed that pre-operative octreotide in patients with macroadenomas led to $50 \%$ cure rates after surgery compared to $23 \%$ in non-treated subjects, confirming previous results by Stevenaert and Beckers [22], while several other studies failed to demonstrate such benefits [23]. It should be noted, however, that in the Carlsen et al. study patients were evaluated only 3 months after surgery and control rates over the long term are still lacking. [24]. The long-acting preparations of both octreotide and lanreotide seem to have relatively equivalent efficacy for acromegaly treatment [25]. Currently, two other molecules are undergoing clinical research - pasireotide, a novel somatostatin analog that binds with high affinity to $\mathrm{SSTR}_{1}, \mathrm{SSTR}_{2}, \mathrm{SSTR}_{3}$, and $\mathrm{SSTR}_{5}$, and a chimeric compound, dopastatin, that acts as a $\mathrm{SSTR}_{2}$ and type 2 dopamine receptor ligand. In a recent phase II study, pasireotide appeared to be superior to octreotide in terms of the proportion of patients attaining full biochemical response after 1 month; more than a third of them had some degree of tumor shrinkage after 3 months of pasireotide treatment [26].

\section{Pegvisomant}

Pegvisomant is the only currently available GH receptor antagonist. It acts by preventing GH receptor dimerization, thus blocking GH effects in the periphery, including the production of IGF-1. Currently, it is indicated when other treatment modalities have failed to achieve IGF-1 normalization. Early trials have reported that this compound effectively suppresses IGF-1 levels within normal ranges in up to $97 \%$ of patients [27], but a recent prospective study demonstrates that such rates are difficult to obtain in clinical settings [28]. The mechanism of action of GH receptor antagonists raises concerns about tumor growth but recent studies have been reassuring in that regard $[28,29]$. Nevertheless, monitoring of tumor mass is advisable in all patients receiving pegvisomant. Combined therapy with SRLs and pegvisomant appears to be as equally effective as pegvisomant monotherapy but with improved cost-effectiveness because of the lower dose needed to achieve IGF-1 normalization [30].

\section{Dopamine agonists}

Dopamine agonists have been used for the management of acromegaly for more than 30 years but low efficacy has discouraged their adoption as monotherapy [31]. Better success rates are reported with cabergoline in tumors with prolactin co-secretion and milder disease activity. 


\section{Radiotherapy}

Radiotherapy can be employed as third- or second-line treatment in patients with persistent or recurrent tumors after surgery and who are resistant or intolerant to pharmacological agents. Conventional fractionated radiotherapy leads to biochemical remission in 40-50\% of patients after 10 years but is associated with a high risk of hypopituitarism, possible development of secondary brain tumors, and an increase in mortality due to cerebro-vascular disease [32]. The use of stereotactic radiosurgery, delivering single fraction focused radiation, results in shorter response times but the long-term efficacy after 10 years of follow-up remains similar to conventional therapy [33].

\section{Implications for clinical practice}

Significant advances in the management of acromegaly have been made in recent years and prognosis for this chronic disease has greatly improved. The combined use of the different treatment approaches allows for attaining disease control or even complete cure in an increasing proportion of patients. A vast spectrum of clinical studies has provided a lot of evidence for the place of the available options in the treatment strategies included in current guidelines. Transsphenoidal surgery performed by experienced neurosurgeons remains the treatment of first choice in many cases. When surgery fails to achieve remission or cannot be used, adjunctive medical therapy may be employed and SRLs are generally preferred as first-line pharmacological treatment. They may also be used as primary and preoperative therapy but whether this will be beneficial for patients still remains to be seen. Pegvisomant is very potent in maintaining biochemical control but its widespread use is limited by its high cost. Radiotherapy is, in many instances, reserved for the most aggressive or resistant tumors.

Despite the progress in management, acromegaly still remains under-diagnosed and under-recognized as a recent study reports [34]. The probability for successful outcomes of treatment is closely related to disease severity and presence of co-morbidities, suggesting that an increased level of suspicion is needed, especially in primary care, when dealing with this disease.

\section{Abbreviations}

GH, growth hormone; IGF-1, insulin-like growth factor 1; SRL, somatostatin receptor ligand; SSTR, somatostatin receptor.

\section{Competing interests}

The authors declare that they have no competing interests.

\section{References}

I. Melmed S: Medical progress: acromegaly. N Engl J Med 2006, 355:2558-73.

2. Holdaway IM, Rajasoorya C: Epidemiology of acromegaly. Pituitary 1999, 2:29-4I.

3. Daly AF, Tichomirowa MA, Beckers A: The epidemiology and genetics of pituitary adenomas. Best Pract Res Clin Endocrinol Metab 2009, 23:543-54.

4. Daly AF, Petrossians P, Beckers A: An overview of the epidemiology and genetics of acromegaly. J Endocrinol Invest 2005, 28:67-9.

5. Schneider HJ, Sievers C, Saller B, Wittchen HU, Stalla GK: High prevalence of biochemical acromegaly in primary care patients with elevated IGF-I levels. Clin Endocrinol (Oxf) 2008, 69:432-5.

FI000 Factor 3.0 Recommended

Evaluated by Philippe Chanson 24 Apr 2008

6. Nachtigall L, Delgado A, Swearingen B, Lee H, Zerikly R, Klibanski A: Changing patterns in diagnosis and therapy of acromegaly over two decades. J Clin Endocrinol Metab 2008, 93:2035-4I.

7. Holdaway IM, Rajasoorya RC, Gamble GD: Factors influencing mortality in acromegaly. J Clin Endocrinol Metab 2004, 89:667-74.

8. Melmed S, Colao A, Barkan A, Molitch M, Grossman AB, Kleinberg D, Clemmons D, Chanson P, Laws E, Schlechte J, Vance ML, Ho K, Giustina A; Acromegaly Consensus Group: Guidelines for acromegaly management: an update. J Clin Endocrinol Metab 2009, 94:1509-17.

FI000 Factor 6.0 Must Read Evaluated by Maria Chiara Zatelli 07 Sep 2009

9. Melmed S, Casanueva F, Cavagnini F, Chanson P, Frohman LA, Gaillard R, Ghigo E, Ho K, Jaquet P, Kleinberg D, Lamberts S, Laws E, Lombardi G, Sheppard MC, Thorner M, Vance ML, Wass JA, Giustina A: Consensus statement: medical management of acromegaly. Eur J Endocrinol 2005, I 53:737-40.

10. Chanson P, Bertherat J, Beckers A, Bihan H, Brue T, Caron P, Chabre O, Cogne M, Cortet-Rudelli C, Delemer B, Dufour H, Gaillard R, Gueydan M, Morange I, Souberbielle JC, Tabarin A; Club Français De L'hypophyse (French Pituitary Club); Société Française Dendocrinologie (French Endocrinology Society): French consensus on the management of acromegaly. Ann Endocrinol (Paris) 2009, 70:92-106.

II. Giustina A, Chanson P, Bronstein MD, Klibanski A, Lamberts S, Casanueva FF, Trainer P, Ghigo E, Ho K, Melmed S: A consensus on criteria for cure of acromegaly. J Clin Endocrinol Metab 2010, [Epub ahead of print].

12. Nomikos P, Buchfelder M, Fahlbusch R: The outcome of surgery in 668 patients with acromegaly using current criteria of biochemical 'cure'. Eur J Endocrinol 2005, I 52:379-87.

13. Kreutzer J, Vance ML, Lopes MB, Laws ER Jr: Surgical management of GH-secreting pituitary adenomas: an outcome study using modern remission criteria. J Clin Endocrinol Metab 200I, 86:4072-7.

14. Abe T, Ludecke DK: Effects of preoperative octreotide treatment on different subtypes of $90 \mathrm{GH}$-secreting pituitary adenomas and outcome in one surgical centre. Eur J Endocrinol 200I, | 145: | 37-45.

15. Petrossians P, Borges-Martins L, Espinoza C, Daly A, Betea D, ValdesSocin H, Stevenaert A, Chanson P, Beckers A: Gross total resection or debulking of pituitary adenomas improves hormonal control of acromegaly by somatostatin analogs. Eur J Endocrinol 2005, I 52:6I-6.

16. Karavitaki N, Turner HE, Adams CB, Cudlip S, Byrne JV, FazalSanderson V, Rowlers S, Trainer PJ, Wass JA: Surgical debulking of pituitary macroadenomas causing acromegaly improves control by lanreotide. Clin Endocrinol (Oxf) 2008, 68:970-5.

17. Colao A, Cappabianca P, Caron P, De Menis E, Farrall AJ, Gadelha MR, Hmissi A, Rees A, Reincke M, Safari M, T'Sjoen G, Bouterfa H, 
Cuneo RC: Octreotide LAR vs. surgery in newly diagnosed patients with acromegaly: a randomized, open-label, multicentre study. Clin Endocrinol (Oxf) 2009, 70:757-68.

18. Freda PU, Katznelson L, van der Lely AJ, Reyes CM, Zhao S, Rabinowitz D: Long-acting somatostatin analog therapy of acromegaly: a meta-analysis. J Clin Endocrinol Metab 2005, 90:4465-73.

19. Mercado M, Borges F, Bouterfa H, Chang TC, Chervin A, Farrall AJ, Patocs A, Petersenn S, Podoba J, Safari M, Wardlaw J; SMS995B240I Study Group: A prospective, multicentre study to investigate the efficacy, safety and tolerability of octreotide LAR (longacting repeatable octreotide) in the primary therapy of patients with acromegaly. Clin Endocrinol (Oxf) 2007, 66:859-68.

20. Bevan JS: Clinical review: The antitumoral effects of somatostatin analog therapy in acromegaly. J Clin Endocrinol Metab 2005, 90:1856-63.

21. Carlsen SM, Lund-Johansen M, Schreiner T, Aanderud S, Johannesen O, Svartberg J, Cooper JG, Hald JK, Fougner SL, Bollerslev J; Preoperative Octreotide Treatment of Acromegaly study group: Preoperative octreotide treatment in newly diagnosed acromegalic patients with macroadenomas increases cure short-term postoperative rates: a prospective, randomized trial. J Clin Endocrinol Metab 2008, 93:2984-90.

22. Stevenaert A, Beckers A: Presurgical octreotide: treatment in acromegaly. Metabolism 1996, 45:72-4.

23. Klibanski A, Melmed S, Clemmons DR, Colao A, Cunningham RS, Molitch ME, Vinik Al, Adelman DT, Liebert KJ: The endocrine tumor summit 2008: appraising therapeutic approaches for acromegaly and carcinoid syndrome. Pituitary 2009, [Epub ahead of print].

24. Beckers A: Does preoperative somatostatin analog treatment improve surgical cure rates in acromegaly? A new look at an old question. J Clin Endocrinol Metab 2008, 93:2975-7.

25. Murray RD, Melmed S: A critical analysis of clinically available somatostatin analog formulations for therapy of acromegaly. J Clin Endocrinol Metab 2008, 93:2957-68.

26. Petersenn S, Schopohl J, Barkan A, Mohideen P, Colao A, Abs R, Buchelt A, Ho YY, Hu K, Farrall AJ, Melmed S, Biller BM; Pasireotide Acromegaly Study Group: Pasireotide (SOM230) demonstrates efficacy and safety in patients with acromegaly: a randomized, multicenter, phase ii trial. J Clin Endocrinol Metab 2010, 95:278I-9.

FI000 Factor 6.0 Must Read

Evaluated by Diego Ferone 16 Jun 2010

27. van der Lely Al, Hutson RK, Trainer PJ, Besser GM, Barkan AL, Katznelson L, Klibanski A, Herman-Bonert V, Melmed S, Vance ML, Freda PU, Stewart PM, Friend KE, Clemmons DR, Johannsson G,
Stavrou S, Cook DM, Phillips LS, Strasburger CJ, Hackett S, Zib KA, Davis RJ, Scarlett JA, Thorner MO: Long-term treatment of acromegaly with pegvisomant, a growth hormone receptor antagonist. Lancet 200I, 358:1754-9.

28. Trainer PJ: ACROSTUDY: the first $\mathbf{5}$ years. Eur J Endocrinol 2009, I6I(Suppl I):S19-24.

\section{Changes Clinical Practice}

FI000 Factor 6.0 Must Read

Evaluated by Maria Chiara Zatelli 25 Feb 2010

29. Buhk JH, Jung S, Psychogios MN, Göricke S, Hartz S, Schulz-Heise S, Klingebiel $R$, Forsting $M$, Brückmann $H$, Dörfler $A$, Jordan $M$, Buchfelder M, Knauth M: Tumor volume of growth hormonesecreting pituitary adenomas during treatment with pegvisomant: a prospective multicenter study. J Clin Endocrinol Metab 2010, 95:552-8.

FI000 Factor 3.0 Recommended

Evaluated by Marcello Bronstein 09 Jun 2010

30. Trainer PJ, Ezzat S, D'Souza GA, Layton G, Strasburger CJ: A randomized, controlled, multicentre trial comparing pegvisomant alone with combination therapy of pegvisomant and long-acting octreotide in patients with acromegaly. Clin Endocrinol (Oxf) 2009, 71:549-57.

FI000 Factor 3.0 Recommended

Evaluated by Maura Arosio 06 Apr 2010

3I. Moyes VJ, Metcalfe KA, Drake WM: Clinical use of cabergoline as primary and adjunctive treatment for acromegaly. Eur J Endocrinol 2008, 159:54|-5.

32. Ayuk J, Clayton RN, Holder G, Sheppard MC, Stewart PM, Bates AS: Growth hormone and pituitary radiotherapy, but not serum insulin-like growth factor-I concentrations, predict excess mortality in patients with acromegaly. J Clin Endocrinol Metab 2004, 89:1613-7.

33. Castinetti F, Nagai M, Morange I, Dufour H, Caron P, Chanson P, Cortet-Rudelli C, Kuhn JM, Conte-Devolx B, Regis J, Brue T: Longterm results of stereotactic radiosurgery in secretory pituitary adenomas. J Clin Endocrinol Metab 2009, 94:3400-7.

FI000 Factor 3.0 Recommended

Evaluated by Francesco Minuto 09 Jul 2009

34. Reid TJ, Post KD, Bruce JN, Nabi Kanibir M, Reyes-Vidal CM, Freda PU: Features at diagnosis of 324 patients with acromegaly did not change from I98I to 2006; Acromegaly remains under-recognized and under-diagnosed. Clin Endocrinol (Oxf) 2009, 72:203-8. 